\title{
Influence Product Domestic Regional Bruto (PDRB), Total Population, And Capital Expenditures On Pad (Regional Generated Revenue) (A Case Study In District And Towns In North Sumatera Province)
}

\author{
Togu Harlen Lbn. Raja \\ Sekolah Tinggi Ilmu Ekonomi LMII \\ Putra Raja Tunggah Hasugian \\ Sekolah Tinggi Ilmu Ekonomi LMII
}

\begin{abstract}
The objective of the research was to find out and to examine the influence of PDRB( Gross Regional Domestic Product), Total Population,and Capital Expenditures on PAD (Regional Generated Revenue), (a case study in districts and towns in North Sumatera Province). The research used causal method with secondary data. The population was 33 district and municipal governments in North Sumatera Province within 5 years (2010-2015) so that there were 198 observations. The samples were taken by using census sampling technique. The data were analyzed by using multiple regression analysis, aided by an SPSS software program. The result of the research showed PDRB( Gross Regional Domestic Product), Total Population, and Capital Expenditures had positive and significant influence onPAD (Regional Generated Revenue)at the Determinance level of 71,3\%. Partially, PDRB( Gross Regional Domestic Product), and Capital Expenditure had positive and significant influence on PAD (Regional Generated Revenue),
\end{abstract}

Keywords: PDRB(Gross Regional Domestic Product), Total Population, and Capital Expenditures on PAD (Regional Generated Revenue)

\section{PENDAHULUAN}

Good governance of the government in a State is an indispensable requirement. The government is obliged to apply good rules in accordance with the provisions that have been applied in running the wheel of government functions, including the rules in the field of state financial management which is applied in the form the application of the principles of good governance.In order to apply good governance, the government of the Republic of Indonessia to reform in the field of state or regional finance management.Regional autonomy policy in the territory of the Unitary Republic of Indonesia (NKRI) regulated in the Act - has brought many changes in each region to implement planned or budgeted development in the APBN / APBD in all fields, in the hope that it can be implemented independently by the Regional Government. The policy was made by the Government through Law Number 32 Year 2004 regarding Regional Government and Act No. 33 of 2004 on Financial Balance between Central and Regional Government.

The policy can be seen and understood from two perspectives. The first perspective is a challenge, the second is an opportunity for the Regional Government. Pemekaran also aims to make public services more efficient and effective. On the basis of that some regions do 
pemekaran to simply shorten the range to the government, given the distance distance between the central government and people living in remote areas very far away.

Contribution of Original Regional Revenues in fulfilling the allocation of funds for regional expenditure should actually be a major source of funds to run the development of the region, but in reality the local government has not able to optimize the potential of the region to explore local revenue sources. The local government still relies on central and provincial assistance in running its government, which means that the autonomous region has not fully succeeded in performing its duties as an autonomous region.

Revenue from a region is obtained by the regional right to collect taxes, issue and circulate money and loan transactions, regional obligations to carry out public services in accordance with local government and pay third party bills, regional revenue, regional expenditures, regional assets directly managed or others money, securities, accounts receivable, goods and other rights which can be valued with money, including property that is separated from the regional company, the wealth of other parties controlled by the regional government in the performance of the duties of the regional government and or public interest, and the wealth of the other parties is obtained by using the facilities provided by the local government.

Regional expenditures and revenues are called Regional Revenue Budgets (APBD), which are the annual financial plans of regional governments discussed and mutually agreed upon by the regional government and the Regional People's Representative Council as determined by local regulations. APBD consists of regional income, regional expenditure and regional financing. Regional expenditures are usually realized for personnel expenditures, goods and services, and for capital expenditures. The three components of APBD, namely regional expenditure, regional income, and regional financing, greatly affect the economic success of a region. If all three are well run then surely give a good impact for economic progress in the region.

Regional spending is grouped into two types, namely indirect spending and direct expenditure. Indirect expenditures include: personnel expenditure, interest expenditure, subsidy spending, grant expenditure, social assistance spending, revenue-sharing to provinces / districts and village administrations, expenditures of financial assistance to provinces and districts and village administrations while direct expenditures include personnel expenditures and services, capital expenditures. To increase regional expenditure, the Total Regional Gross Regional Domestic Product (GRDP) should be further increased. As the GRDP gets bigger, the greater the revenue earned by districts / cities with the greater revenue earned by the regions, then the allocation of spending by the central government will be greater or greater than ever with to increase local potentials in the area for the benefit of public services (Lin and Lun 2000 in Gorahe et al., 2013: 3).

Expenditure Regional spending is seen from the development of the number of residents in an area, if the growing number of people will require a larger budget. Due to the increasing number of residents is increasing the budget also increased the area. Due to the rising population demands a logical consequence of the improvement of public facilities and infrastructure, both in terms of quantity and quality. Increasing the number of people growing larger then require a larger budget, so that the quality of economic growth is better, population growth must always be controlled.

In its implementation, the financial management process of the State or Region encompasses a whole set of activities relating to the management of such objects above from the formulation 
of policies and decision-making up to accountability. Finally, the purpose of State or local financial management is to produce policies, activities and legal relations relating to the ownership and / or control of financial objects of State / Regional Finance in the context of organizing the life of the nation and state.

Therefore, the purpose of this study is to know and analyze the effect of Gross Regional Domestic Product, Total Population, and Capital Expenditures simultaneously and partially to on Regional Generated Revenue (PAD), local government.

This study is also expected to provide information and inputs to local governments on the influence of Gross Regional Domestic Product (GDP), Total Population, and Capital Expenditures on Regional Generated Revenue (PAD), (a case study in districts and towns in North Sumatra Province ).

\section{THE LITERATURE AND DEVELOPMENT OF HYPOTHESES \\ Regional Generated Revenue (PAD)}

According to Law No. 17 of 2003, regional revenues are the rights of local governments recognized as enhancers of net worth. Article 157 of Law No.32 of 2004 and Article 6 of Law no. 33 of 2004 explains that the source of PAD consists of local taxes, user charges, the results of the management of separated regional wealth and other legitimate PAD.

Based on the Regulation of the Minister of Home Affairs Number 13 Year 2006 Guidelines on Regional Financial Management Article 26 paragraph (1) stated that the original revenue of the region consists of:
1) Local Tax.
2) User charges.
3) Result of regionally-owned enterprises and management result of separated areas.
4) Other valid genuine regional revenue

\section{Product Domestic Regional Bruto (PDRB) according to Constant prices}

According to (Imamul Arifin, 2007: 97) states that Gross Domestic Product is the value of goods and services end generated by people in a region (region), both at the provincial and district / city levels.

According to (Imamul Arifin, 2007: 97) states Gross Domestic Product at Constant Price must be determined base year first, ie year when economy is in good condition so that prices remain stable and constant.

\section{Total Population}

The BPS-Statistics Indonesia Statistics Agency (2013) describes "the population is all persons domiciled in the geographical area of the Republic of Indonesia for 6 months or more and or those who are domiciled for less than 6 months but whose purpose is to settle".

According to Said (2001), the population is "the number of people who reside in a region at a certain time and is the result of demographic processes of fertility, moertality and migration."

\section{Capital Expenditure}

The amounts with the purchase / procurement values or the construction of tangible fixed assets are budgeted in capital expenditure only at the purchase price / asset (Permendagri 13 Tahun 2006). 101 / PMK.02 / 2011 Capital Expenditures are used for, among others: Land Capital Expenditures, Capital Expenditures for Equipment and Machinery, Capital Expenditure of Buildings and Buildings, Irrigation and Network Capital Expenditures, Other Capital 
Expenditures and Capital Expenditures of Public Service Bodies (BLU). Capital expenditure consists of capital expenditures for acquisition of land, buildings and buildings, equipment and intangible assets (PP No. 24/2005).

\section{Conseptual framework}

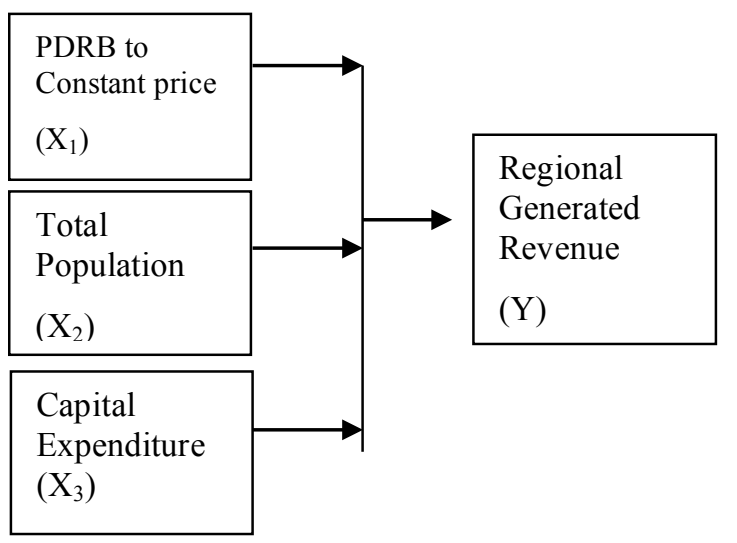

\section{Gambar 1 Conseptual framework of Research}

\section{Research Hypothesis}

Hipotesis Penelitian berdasarkan telaah literatur dan kerangka konsep adalah:

PDRB( Gross Regional Domestic Product), Total Population,and Capital Expenditures have significant partial and simultaneous effect on PAD (Regional Generated Revenue)

\section{METHODOLOGY}

This type of research can be regarded as causal research (causal effect), aims to see the relationship relationship between two or more variables with the replication model from previous research to answer the problem and research objectives.

The data used in this study are secondary data related to Realization of APBD data, Realization of constant Price GDP and Realization of Population published by Central Bureau of Statistics of Regency / Municipality in North Sumatera Province 2010-2015.

The population used in this study is the district and municipal governments in the region of North Sumatra Province which amounted to 33 districts / cities with a period of 6 years (20102015 ) so that the amount of research data as much as 33 districts / cities x 6 years = 198 data research.

Methods The sampling of this study using a saturated samples ie all members of the population in the district / city in the Province of North Sumatra to sample research. 
Tabel 1. Definisi Operasional dan Pengukuran Variabel

\begin{tabular}{|c|c|c|c|c|}
\hline $\begin{array}{c}\text { Jenis } \\
\text { Variabel }\end{array}$ & $\begin{array}{c}\text { Nama } \\
\text { Variabel }\end{array}$ & Definisi Operasional & Parameter & Skala \\
\hline $\begin{array}{l}\text { Variabel } \\
\text { Dependen }\end{array}$ & $\begin{array}{l}\text { Regional } \\
\text { Generated } \\
\text { Revenue } \\
\text { (PAD) }\end{array}$ & $\begin{array}{l}\text { Receipts gained by local governments } \\
\text { from sources within their own areas } \\
\text { levied according to local regulations in } \\
\text { accordance with applicable legislation } \\
\text { consisting of local taxes, user charges, } \\
\text { the results of separated regional } \\
\text { wealth management and other } \\
\text { legitimate PAD }\end{array}$ & $\begin{array}{l}\text { Realization of } \\
\text { Regional Generated } \\
\text { Revenue (PAD) Year } \\
\text { Budget } 2010-2015\end{array}$ & Ratio \\
\hline \multirow[t]{3}{*}{$\begin{array}{l}\text { Variabel } \\
\text { Independen }\end{array}$} & $\begin{array}{l}\text { Product } \\
\text { Domestic } \\
\text { Regional } \\
\text { Bruto } \\
\text { (PDRB) } \\
\text { prices } \\
\text { constant }\end{array}$ & $\begin{array}{l}\text { The Gross Domestic Product of the } \\
\text { prices constant must be determined in } \\
\text { the base year first, ie the year when } \\
\text { the economy is in good condition so } \\
\text { that prices remain stable and constant. }\end{array}$ & $\begin{array}{l}\text { Realization Product } \\
\text { Domestic bruto prices } \\
\text { constant } \\
\text { Year Budget 2010- } \\
2015\end{array}$ & Ratio \\
\hline & $\begin{array}{l}\text { Total } \\
\text { Population }\end{array}$ & $\begin{array}{l}\text { Funds sourced from APBN allocated to } \\
\text { regions based on percentage figures to } \\
\text { fund regional needs in the context of } \\
\text { decentralization }\end{array}$ & $\begin{array}{l}\text { Realization total } \\
\text { population } \\
\text { Year Budget } 2010- \\
2015\end{array}$ & Ratio \\
\hline & $\begin{array}{l}\text { Capital } \\
\text { Expenditure }\end{array}$ & $\begin{array}{l}\text { Expenditure of the budget to acquire } \\
\text { fixed assets and other assets that } \\
\text { provide benefits over one accounting } \\
\text { period, which include, among others, } \\
\text { acquisition of land, buildings and } \\
\text { buildings, intangible assets equipment }\end{array}$ & $\begin{array}{l}\text { Realization Capital } \\
\text { Expenditure } \\
\text { Year Budget 2010- } \\
2015\end{array}$ & Ratio \\
\hline
\end{tabular}

\section{Metode Penelitian}

Data analysis in the research used include descriptive statistics, classical assumption test, multiple linear regression model on $\alpha$ or $5 \%$ significance level. The model of the regression equation includes:

Model Testing the first Hypothesis (H1):

$\mathrm{Y}=\mathrm{a}+\mathrm{b}_{1} \mathrm{PDRB}+\mathrm{b}_{2} \mathrm{JP}+\mathrm{b}_{3} \mathrm{BM}+\mathrm{e}$

Information :

$\mathrm{Y}=$ Regional Generated Revenue

$\mathrm{a}=$ Constanta

$b_{1}-b_{3}=$ Coefisient independent variable

$\mathrm{PDRB}=$ Product Domestic Regional Bruto

$\mathrm{JP}=$ Total Population

$\mathrm{BM}=$ Capital Expenditure

$\varepsilon=$ error

\section{Deskriptive Statistics Tests}

\section{RESULTS AND DISCUSSION}

Descriptive statistical analysis is used to find out the description of data viewed from the maximum value, minimum value, mean value, and standard deviation value, from GRDP (Total 
Regional Domestic Product), Total Population, and Capital Expenditures and PAD (Regional Generated Revenue

Tabel 4.1 Statistic Deskriptive dari PDRB, Total population, Capital Expenditure, dan PAD Descriptive Statistics

\begin{tabular}{|l|r|r|r|r|r|}
\hline & N & Minimum & Maximum & Mean & Std. Deviation \\
\hline PAD (Y) & 198 & 958.00 & 1679237.00 & 80726.9293 & 2.15732 E5 \\
PDRB (X1) & 198 & 164880.00 & $1.24 E 8$ & 7.0000 E6 & 1.45585 E7 \\
Jumlah Penduduk (X2) & 198 & 40505.00 & 2210624.00 & 405717.9596 & 4.61354 E5 \\
Belanja Modal (X3) & 198 & 22261.00 & 1080394.00 & 176748.6919 & 1.38349 E5 \\
Valid N (listwise) & 198 & & & & \\
\hline
\end{tabular}

Based on Table 4.1, it is known that the average value of PAD is 80726.92 and the standard deviation value of PAD is 215732 (2.15732E5). While the minimum value of PAD is 958 and the maximum value of PAD is 1679237. The average value of GRDP is 7000019.49 (7.0000E6) and the standard deviation value of GRDP is 14558460.67 (1.45585E7). While the minimum value of GRDP is 164880 and the maximum value of GRDP is 124277480 (1.24E8). The average value of the population is 405717.95 and the standard deviation of the population is 461353.92 . While the minimum value of the population is 40505 and the maximum value of the population is 2210624 . The average value of capital expenditure is 176748.69 and the standard deviation of capital expenditure is 138349.03 . While the minimum value of capital expenditure is 22261 and the maximum value of capital expenditure is 1080394.

\section{Classic Assumption Test Normality test}

In this study, normality test of residual by using Kolmogorov-Smirnov test. The level of significance used $\alpha=0.05$. The basis for the decision is to look at the probability $\mathrm{p}$, with the following conditions (Ghozali, 2013).

If the probability value $\mathrm{p} \geq 0.05$, then the assumption of normality is met. If the probability is $<0.05$, then the assumption of normality is not met.

Tabel 4.2 Normality Test

One-Sample Kolmogorov-Smirnov Test

\begin{tabular}{|ll|r|}
\hline \multicolumn{2}{|c|}{ One-Sample Kolmogorov-Smirnov Test } \\
\hline Normal Parameters ${ }^{\text {a, }, 0}$ & $\begin{array}{c}\text { Unstandardized } \\
\text { Residual }\end{array}$ \\
& Mean & 198 \\
Most Extreme Differences & Std. Deviation & .0000000 \\
& Absolute & .59837446 \\
& Positive & .051 \\
& Negative & .025 \\
Kolmogorov-Smirnov Z & & .051 \\
Asymp. Sig. (2-tailed) & .722 \\
a. Test distribution is Normal. & .675 \\
b. Calculated from data.
\end{tabular}

Normality test results can be seen through the Kolmogorov-Smirnov One-Sample Test which shows the probability value p or Asymp.Sig. (2-tailed) of 0.675 . Because the probability value $p$, ie 0.675 , is greater than the level of significance, ie 0.05 . This means the assumption of normality is met. 

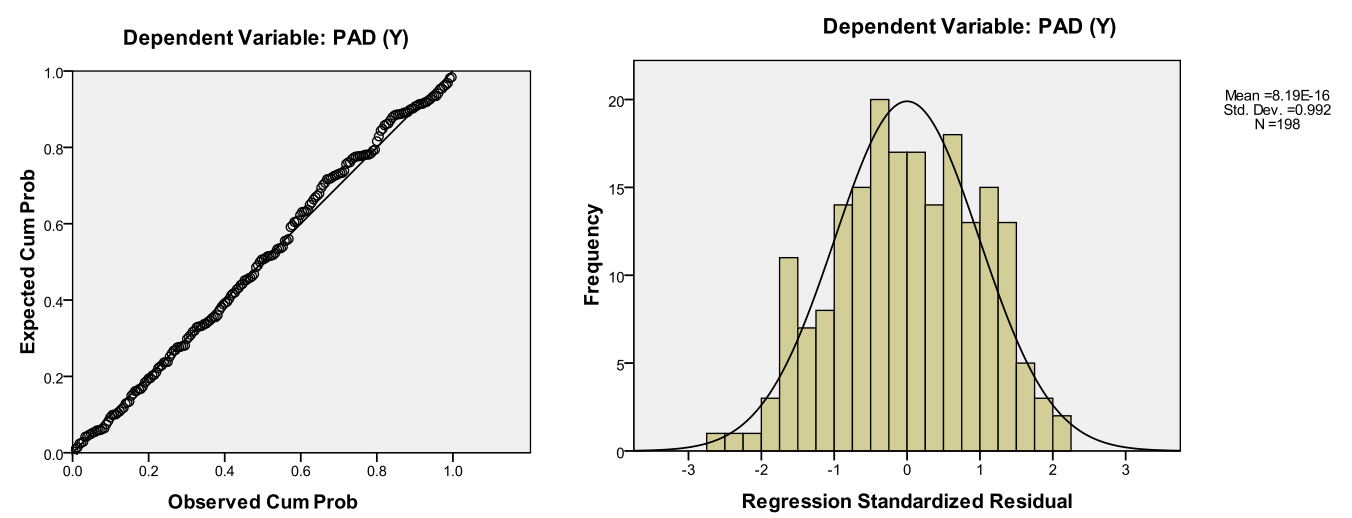

Gambar 4.1 Normality test with Normal Probability Plot and Histogram

Note that according to Figure 4.1, in the normalized probability plot normality test, the points tend to be close to the line and based on the normality test with the histogram, the normal shaped curve. Then the assumption of normality is met.

\section{Multicolinearity Test}

To check whether there is multicolinearity or can not be seen from the value of variance inflation factor (VIF). VIF values greater than 10 are indicated a free variable occurs multicollinearity (Ghozali, 2013).

Tabel 4.2 Uji Multicollinearity

\begin{tabular}{|c|c|c|}
\hline \multirow[b]{2}{*}{ Model } & \multicolumn{2}{|c|}{ Collinearity Statistics } \\
\hline & Tolerance & VIF \\
\hline 1 (Constant) & & \\
\hline PDRB (X1) & .264 & 3.791 \\
\hline Jumlah Penduduk (X2) & .287 & 3.481 \\
\hline Belanja Modal (X3) & .599 & 1.668 \\
\hline
\end{tabular}

The multicollinearity test shows, the VIF value of GRDP is 3.791 , the VIF value of the Population is 3,481 and the VIF value of capital expenditure is 1,668 . Since each VIF value is not greater than 10 and the tolerance value is greater than 0.1 , there is no severe multicollinearity.

\section{Heteroscedasticity Test}

The Glejser statistical test was chosen because it was able to guarantee the accuracy of the results compared to the plot test chart that could cause bias. The Glejser test is performed by regressing the independent variable against its residual absolute value on the dependent variable (Ghozali, 2013). The criteria used to state whether heteroscedasticity or not among observational data can be explained using the significance coefficients. The coefficient of significance should be compared with a predetermined level of significance (5\%). If the significance coefficient is greater than the specified level of significance, it can be concluded that there is no heteroscedasticity (homoscedasticity). If the significance coefficient is less than the defined level of significance, then it can be concluded heteroskedastisitas occur.

Table 4.3 test Heteroscedasticity with Glejser Test 


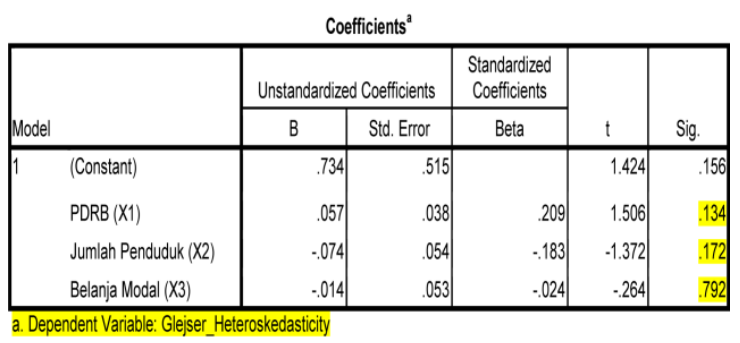

Based on the Glejser test, it shows the probability value or Sig. of GDP is 0.134 , the probability value or Sig. of the Population is 0.172 , and the probability value or Sig. of capital expenditure is 0.792 . Because the whole value of Sig. greater than 0.05 (not significant), it was concluded that there was no heteroscedasticity (Gujarati, 2003, Ghozali, 2013).

Since all probability values (Sig.) $>0.05$, it is concluded that there are no symptoms of heteroskedastistas.Based on Figure 4.2, the points spread above and below the number 0, so it is not concluded heteroscedasticity.

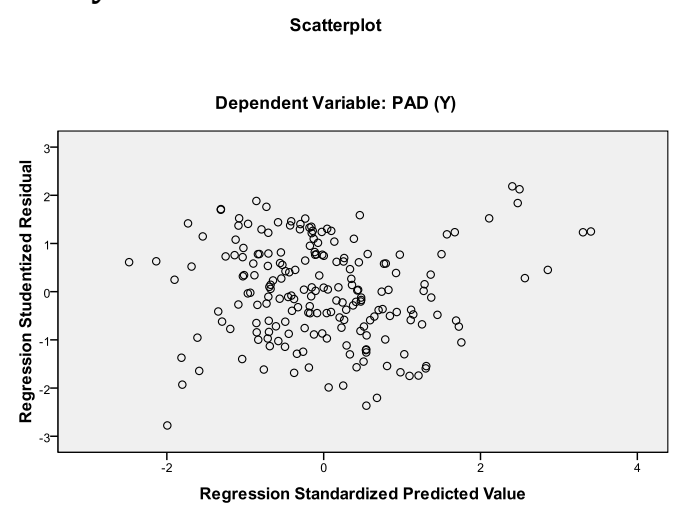

Gambar 4.2 Uji Heteroscedasticity

\section{Autocorrelation Test}

Table 4.4 test Autocorrelation with Durbin-Watson Test

\begin{tabular}{|l|r|}
\hline Model & Durbin-Watson \\
\hline 1 & 1.581 \\
\hline
\end{tabular}

The statistical value of the Durbin-Watson test that is smaller than 1 or greater than 3 indicates an autocorrelation. Field (2009: 220-221) states as follows.

"The size of the Durbin-Watson statistic depends upon the number of predictors in the model and the number of observations. For accuracy, you should look up the exact acceptable values in Durbin and Watson's (1951) original paper. As very conservative rule of thumb, values less then 1 or greater than 3 are definitely cause for concern; however, values closer to 2 may stil be problematic depending on your sample and model".

According to Table 4.4, the value of the Durbin-Watson statistic is 1.581 . Note that since the Durbin-Watson statistic value lies between 1 and 3 , ie $1<1.581<3$, then non-autocorrelation assumptions are met. In other words, there are no symptoms of high autocorrelation in residuals. 


\section{Analysis of Coefficient of Determination}

Coefficient determination $\left(R^{2}\right)$ is a value (value of proportion) that measures how much the ability of the independent variables used in the regression equation, in explaining the variation of the dependent variable.

Tabel 4.5 Coefficient Determination Model Summary ${ }^{\circ}$

\begin{tabular}{|l|r|r|r|r|r|}
\hline Model & \multicolumn{1}{|c|}{$R$} & R Square & $\begin{array}{c}\text { Adjusted R } \\
\text { Square }\end{array}$ & $\begin{array}{c}\text { Std. Error of the } \\
\text { Estimate }\end{array}$ & Durbin-Watson \\
\hline 1 & $.844^{2}$ & .713 & .708 & .60298 & 1.581 \\
\hline
\end{tabular}
a. Predictors: (Constant), Belanja Modal (X3), Jumlah Penduduk (X2), PDRB (X1)
b. Dependent Variable: PAD (Y)

Based on Table 4.5, it is known that the coefficient of determination (R-Square) is 0.713 . The value can be interpreted as PDRB variable, population, and capital expenditure, together can explain or explain variation of PAD equal to $71,3 \%$, the rest equal to $28,7 \%$ explained by variable or other factor.

\section{Test Significance of Simultaneous influence (Uji $F$ )}

\section{TESTING THE RESEARCH HYPOTHESIS}

Tabel 4.6 Simultaneous influence test with $F$ test

\begin{tabular}{|c|c|c|c|c|c|c|}
\hline \multicolumn{7}{|c|}{ ANOVA $^{\circ}$} \\
\hline Mo & & Sum of Squares & df & Mean Square & $\mathrm{F}$ & Sig. \\
\hline \multirow[t]{3}{*}{1} & Regression & 175.018 & 3 & 58.339 & 160.454 & .000 \\
\hline & Residual & 70.536 & 194 & .364 & & \\
\hline & Total & 245.555 & 197 & & & \\
\hline
\end{tabular}

Based on Table 4.6, it is known:

$\mathrm{F}$ arithmetic is $160,454>\mathrm{F}$ value table 2,651

Probability value (Sig.) $0,000<0.05$

So GRDP, population, and capital expenditure simultaneously have a significant effect on PAD.

\section{Multiple linear regression analysis and partial effect significance test (Uji t)}

Table 4.7 presents the regression coefficient value, as well as the statistical value t for partial effect test.

Tabel 4.7 Test of Significance Partial influence (Uji $t$ )

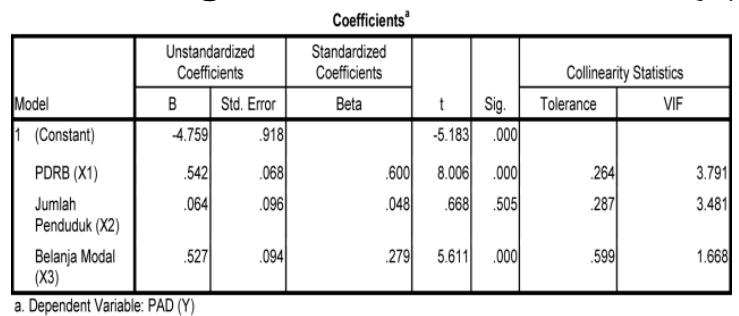

Based on Table 4.7, we get the following multiple linear regression equation.

$$
Y=-4,759+0,542 X 1+0,064 X 2+0,527 X 3+e
$$

Based on the multiple linear regression equation is known: 
$\Rightarrow$ The value of regression coefficient of PDRB is 0.542 , which is positive. The value can be interpreted PDRB have a positive effect on PAD. Given the value of Sig 0,000<0,05 and t value of 8,006 is in area $\mathrm{H}_{1}$, so PDRB have significant effect to PAD.

$\Rightarrow$ The regression coefficient value of the population is 0.064 , which is positive. This value can be interpreted by the number of people positively affecting PAD. Given Sig value $0,505>0,05$ and $t$ value 0,668 is in area $H_{0}$, hence number of population have no significant effect to PAD.

$\Rightarrow$ The regression coefficient value of capital expenditure is 0.527 , which is positive. The value can be interpreted capital expenditure has a positive effect on PAD. Given the value of Sig 0,000<0,05 and t value 5,611 is in area $H_{1}$, hence capital expenditure have significant effect to PAD.

Picture 4.3 prests the decision area based on $t$ test.

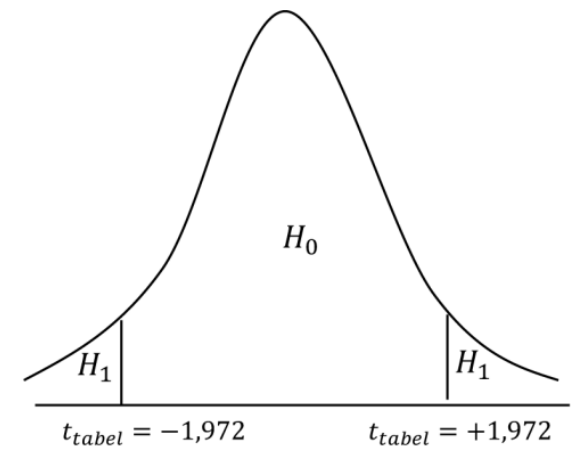

Gambar 4.3 Daerah Keputusan berdasarkan Uji t

\section{Discussion of research result}

\section{Pengaruh Produk Domestik Regional Bruto terhadap Pendapatan Asli Daerah}

Based on table 4, it shows that the variable of Gross Domestic Product (PDRB) has a positive and significant effect On Regional Generated Revenue (PAD).

\section{Influence Total Population on Regional Generated Revenue (PAD)}

Based on table 4, shows that the variable Total population has no significant effect on. Regional Generated Revenue (PAD).

\section{Influence Capital Expenditure on Regional Generated Revenue (PAD)}

Based on table 4, it shows that Capital Expenditure variable has positive and significant influence to Regional Generated Revenue (PAD).

\section{CONCLUSIONS}

\section{CONCLUSIONS, LIMITATIONS AND SUGGESTIONS}

Based on the results of simultaneous testing of Domestic Regional Domestic Product (PDRB), Total Population, And Capital Expenditure, significant effect on on Regional Generated Revenue (PAD) a case study in districts and towns in North Sumatera. Partially PDRB Price Constant And Capital Expenditure have significant effect to Regional Generated Revenue (PAD), While Total Population No significant effect on Regional Generated Revenue (PAD).

\section{LIMITATIONS}

1. This research only uses observation year for 6 year budget (2010-2015).

2. The population used in this study only District/City in the Province of North Sumatra (33 District/City). 
3. This research only uses and analyzes 3 independent variables, namely Product of price gross (PDRB) constant, Total population, Capital Expenditure, 1 dependent variable that is Regional Generated Revenue (PAD).

\section{SUGGESTIONS}

1. For further researcher is suggested to increase observation year research and use other research variables as moderating variable.

2. For further researchers suggested Add Population used in the study, if possible the population is all districts/ cities in the island of Sumatra, Java, or Indonesia.

3. For further researchers who want to do further research that resembles this research is suggested to increase the number of research variables, among others: Tax receipts, Fund of regional autonomy, the remaining more budget financing

\section{Reference}

Agenor, Pierre R. dan Blanca Moreno-Dodson. 2006." Public Infrastructure and Growth: New channels and Implications". World Bank Policy Research Working Paper 4064.

Badan Pusat Statistik Sumatera Utara. 2016. "Statistik Keuangan Pemerintah Daerah Sumatera Utara Tahun 20102015".http://sumut.bps.go.id

Darise, Nurlan, 2008. “Akuntansi Keuangan Daerah," Jakarta, Cetakan pertama, Penerbit PT Indeks, Jakarta.

Darwanto dan Yustikasari, Yulia. 2007. “Pengaruh Pertumbuhan Ekonomi, Pendapatan Asli Daerah, Dana Alokasi Umum Terhadap Pengalokasian Belanja Modal”.Simposium Nasional Akuntansi X Makassar 26-28 Juli 2007.

Erlina, Sirojuzilam, Rasdianto, 2012. Pengelolaan dan Akuntansi Keuangan Daerah, USU Press, Medan.

Ghozali, Imam. 2013. “Aplikasi Analisis Multivariate dengan Program IBM SPSS 21 Update PLS Regresi”.Edisi 7.Universitas Dipenegoro.Semarang.

Halim, Abdul 2008. “Akuntansi Keuangan Daerah”, Edisi Ketiga, Salemba Empat, Jakarta. Prapitorini, Januarti, 2007.

Imamul Arifin, 2007, Membuka Cakrawala Ekonomi. Bandung: Grafindo

Irdha Anisyah Marsudi Gorahe dkk, 2013, “ Analisis Belanja Daerah dan factor-faktor yang mempengaruhinya di Provinsi Sulawesi Utara", Jurnal, Sulawesi Utara : Universitas Sam Ratulangi Manado.

Lubis, Ade Fatma. 2015. “Metode Penelitian Akuntansi dan Format Penulisan Tesis”. Medan : USU Press.

Peraturan Menteri Keuangan, 2006, Peraturan Menteri Keuangan Republik Indonesia Nomor 45/PMK.02/2006 tentang "Pedoman Pelaksanaan dan Mekanisme Pemantauan Defisit Anggaran Pendapatan di Belanja Daerah dan Pinjaman Daerah",Jakarta.

Peraturan Menteri Keuangan, 2011, Peraturan Menteri Keuangan Republik Indonesia Nomor 101/PMK.02/2011 tentang "Klasifikasi Anggaran", Jakarta.

Peraturan Presiden, 2010, Peraturan Pemerintah Republik Indonesia Nomor. 5 tahun 2010 tentang RPJMN Tahun 2010-2014", Jakarta.

Peraturan Menteri Dalam Negeri, 2006, Peraturan Menteri Dalam Negeri Republik Indonesia Nomor 13 Tahun 2006 tentang "Pedoman Pengelolaan Keuangan Daerah", Jakarta.

Peraturan Pemerintah, 2005, Peraturan Pemerintah Republik Indonesia Nomor. 58 tahun 2005 tentang

"Pengelolaan Keuangan Daerah", Jakarta.

Renyowijoyo dan Muindro, 2010. "Akuntansi Sektor Publik", Edisi Kedua, Mitra Wacana Media, Jakarta.

Starub, Stephane. 2008. "Infrastructure and Growth in Developing Countries: Recent Advances and Research Challenges", Working Paper Development Research Departement. Research Support Team. World Bank .

Tausikal, Askam. 2008. “Pengaruh Dana Alokasi Umum, Dana Alokasi Khusus, Pendpatan Asli Daerah, dan Produk Domestik Regional Bruto Terhadap Belanja Modal Pemerintah Daerah Kabupaten/Kota di Indonesia”, Jurnal Telaah \& Riset Akuntansi.Vol.1, No.2 Juli 2008.Universitas Pattimura Ambon.

Undang-Undang Republik Indonesia, 2000, Undang-Undang Republik Indonesia Nomor 34 Tahun 2000 Tentang Perubahan UU No.18 Tahun 1997 Tentang "Pajak Daerah dan Retribusi Daerah". 
Raja, T. H. L., \& Hasugian, P. R. T. (2018). Influence Product Domestic Regional Bruto (PDRB), Total Population, And Capital Expenditures On Pad (Regional Generated Revenue) (A Case Study In District And Towns In North Sumatera Province). Advances in Social Sciences Research Journal, 5(1) 185-196.

Undang-Undang Republik Indonesia, 2003, Undang-Undang Republik Indonesia Nomor 17 Tahun 2003tentang"Keuangan Negara".

Undang-Undang Republik Indonesia, 2004, Undang-Undang Republik Indonesia 32 Tahun 2004 tentang "Pemerintah Daerah",

Undang-Undang Republik Indonesia, 2004, Undang-Undang Republik Indonesia Nomor 33 Tahun 2004tentang "Pertimbangan Keuangan Antara Pemerintah Pusat dan Pemerintah Daerah".

Undang-Undang Republik Indonesia, 2009, Undang-Undang Republik Indonesia Nomor 28 Tahun 2009 tentang“ Pajak dan Retribusi Daerah".

www.depkeu djpk.go.id 